\title{
Beyond the Shadow of William Briggs Part I: Setting the Stage and Introducing the Players
}

Janet B. Friskney ${ }^{\dagger}$

For nearly forty years Lorne Pierce's The Chronicle of a Century and The House of Ryerson I 829-1954 and W. Stewart Wallace's The Ryerson Imprint prevailed as the cornerstone of the literature relating to The Ryerson Press and its forerunner, The Methodist Book and Publishing House. ${ }^{\mathrm{I}}$ The recent spate of scholarly activity surrounding the House is long overdue; that it is being pursued by individuals from a variety of academic backgrounds reflects the establishment's richness as a source of study and bodes well for a broader and more encompassing understanding of what was an important Canadian cultural institution. ${ }^{2}$ New information brought forward by such endeavours will inevitably demand a revision of previously held perceptions. A case in point is the emphasis which has traditionally been placed on William Briggs as the individual responsible for the House's book publishing initiatives and its commitment to Canadian writing in the late nineteenth and early twentieth centuries. While Briggs was a key player in the House's publication of Canadian-authored titles, to hold him solely or primarily accountable is both misleading and inappropriate; it denies an important historical context and leaves unacknowledged the initiatives of other important individuals connected with the House during his tenure (1879-1919).

When an effort is made to place the House in context, it becomes apparent that numerous forces were at work to create an environment conducive to an encouragement of Canadian writing during Briggs's stewardship. Prominent among them were the House's own early history, the Canadian Methodist, literary and book publishing climate of the day, and the general state of the business. Neither

+ Janet B. Friskney is a doctoral student in history at Carleton University. Part II ('Canadian-Authored Titles and the Commitment to Canadian Writing') of 'Beyond the Shadow of William Briggs' will be published in a future issue of the Papers/Cahiers. 
should agency be ignored. A number of the House's employees emerge as particularly influential. Exploring these considerations here will assist in setting the stage and introducing the players for a subsequent examination of Canadian-authored titles published by the House between 1879 and 1919 , the latter discussion to take place in a future article.

\section{The House's Early History ${ }^{3}$}

The Methodist Book and Publishing House finds a place in continuums of both Methodist publishing and Canadian publishing; its ties to both religion and nation influenced the course of its development. When the Methodist Episcopal Church in Canada initiated the House with the founding of the Christian Guardian in 1829, it brought a tradition of Methodist publishing to Upper Canada that had precursors in both Great Britain and the United States. ${ }^{4}$ However, the paper's founding was intimately linked to the political and social conditions existing in Upper Canada at that time; ${ }^{5}$ among its primary objectives were the defining and defending of Methodism's place in Upper Canadian society. ${ }^{6}$ Thus, while the church clearly placed its operation in a continuum of Methodist publishing, from the beginning it was actively engaged in adapting that transplanted tradition to serve - and survive - in an evolving Upper Canadian environment.

Like its contemporaries, the House had to contend with difficulties, such as unpaid subscriptions and a small market scattered over a large geographic area, that were inherent in the Upper Canadian market. As the Methodists had a healthy respect for sound business practices and hoped to redirect profits generated by the establishment to other church initiatives, it is not surprising that the House's early overseers chose to strike a balance between the Methodist imperative to publish and disseminate morally sound material and the financial repercussions of doing so in the Upper Canadian market. Despite early financial concerns, the House's activities through its first fifty years expanded from the production of a single denominational newspaper to include commercial printing, retail and wholesale bookselling, and the publication of Sunday school periodicals and the Canadian Methodist Magazine (est. I875). During Samuel Rose's term as Book Steward, which immediately preceded that of Briggs, an increasingly commercial awareness was evident in the House's management, with customers being 
urged to compare prices and advertising and sales techniques growing more sophisticated. Unlike its British and American brethren, however, the House in its early years did not adopt book publishing - the most financially risky of publishing endeavours - as a fundamental part of its operations. With rare exceptions, books that did emerge from the press between I829 and I879 fell within the realm of ecclesiastical undertakings, such as volumes on church doctrine and liturgy, or were ventures for which 'production costs were covered either by the author, by subscription, or by pre-publication sale. ${ }^{7}$

Throughout its early history, the Methodist Book and Publishing House's religious affiliation was very much in evidence. Ministers served as agents for the House and filled the official managerial positions of Book Steward (general manager) and Editors. Changes in the state of Canadian Methodism also made an impact. For example, when the Methodist Episcopal Church in Canada united with the British Wesleyans in 1833 /at which time the Canadians changed their name to the 'Wesleyan Methodist Church in Can-

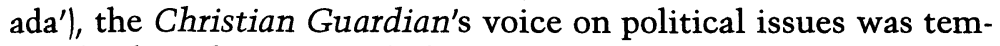
pered to be in keeping with the British Wesleyans' more deferential attitude toward the establishment. Similarly, when the Wesleyan Methodist Church in Canada joined forces with the Conference of Eastern British America and the Methodist New Connexion Church in 1874 to form the Methodist Church of Canada, laymen were added to the Book Committee - the House's overseeing body which was akin to a board of directors - in response to the New Connexion Methodists' strong tradition of lay participation.

During its first half century the House also demonstrated an ever-strengthening consciousness of place in its publishing initiatives as Canadian Methodism adapted to and developed within its particularly Canadian milieu. With the publication of Sacred Harmony in the mid-I830s, for instance, the House sought to produce a music book that would meet the needs and reflect the tastes of an ethnically mixed British North American community. ${ }^{8}$ In the 1840 s its first Sunday school periodical, the Sunday School Guardian, encouraged local submissions, arguing that

one of the strongest reasons why the continuance of this periodical is highly desirable and important, is for the purpose of having a suitable medium to communicate interesting items of intelligence respecting our own affairs; and to record and make improvements upon events which may transpire amongst ourselves, or with which 
we are more immediately concerned. We might obtain juvenile periodicals published in other places, but they must necessarily be filled with subjects of less interest to us than those which belong to our own operations. ${ }^{9}$

By mid-century a concern for developing an Upper Canadian Methodist literature - in keeping with the efforts of British and American Methodists in their respective countries - had begun to emerge within the church community. Though one reader of the Christian Guardian would deplore the slowness of that literature's development in $1865,{ }^{\text {IO }}$ the 1850 , I 860 s and 1870 s saw the House issuing a number of works chronicling events and individuals significant to Upper Canadian Methodism, among them George Playter's History of Methodism in Canada and John Carroll's multi-volume Case and his Contemporaries. Rev. W.H. Withrow's initial editorial for the Canadian Methodist Magazine in January 1875 marked a watershed. He not only articulated as one of his objectives that 'most of our articles ... [ [should] have a distinctly national flavour' and be 'an indigenous growth' and 'racy of the soil,', I but also put forth his belief in a Methodist literature that would transcend sectarian limits:

It is a literature loyal to Methodism and to truth that we wish to develop - a literature that shall unfold our principles, defend our doctrines and illustrate our polity. Yet it is not a narrow, sectarian literature that we seek to educe. Methodist bigotry is the worst kind of bigotry, because it is so opposed to the genius of Methodism's free institutions. Whatsoever things are true, whatsoever things are honest, whatsoever things are just, whatsoever things are pure, whatsoever things are lovely, whatsoever things are of good report; these things we shall endeavour to promote and to urge upon the hearts and consciences of our readers. ${ }^{\mathrm{I} 2}$

Even as Withrow established the magazine as an exponent of the Methodist Church of Canada, he set out his ambition that the appeal of its contents should extend beyond the boundaries of his faith. In that endeavour he found himself constrained by the more conservative members of the Book Committee, who were particularly disenchanted with his inclusion of fiction in the journal; ${ }^{13}$ nevertheless, the Canadian Methodist Magazine was an important component in the House's commitment to indigenous literature and the breadth of the material it included - religious, historical, 
scientific, biographical, and literary - anticipated the broader commitment to Canadian writing which presented itself so clearly during Briggs's stewardship.

\section{Canadian Methodism}

Three issues relating to Canadian Methodism between 1879 and I 919 emerge as important: a newly national Methodist perspective, changing attitudes toward literature, and the emergence of the social gospel. The Methodist union of $\mathrm{I} 874$ was followed in $\mathrm{I} 884$ by the merger of the Methodist Church of Canada, the Methodist Episcopal Church of Canada, the Primitive Methodist Church of Canada, and the Bible Christian Church in Canada to form the Methodist Church. These unions, motivated as they were by the Methodists' aspiration to consolidate their various factions into a national church, encouraged the resulting body to be national in program and outlook. ${ }^{14}$ Throughout the period 1879 to I9I9 the Methodist Church demonstrated a strong patriotism and conservative nationalism, supporting the federal government's position on the Northwest rebellion in I 885 and Canada's involvement in the First World War, as well as designating the assimilation of incoming immigrants as one of its patriotic duties. The church also interested itself more keenly in the state of Canadian society in general, focusing particularly on such matters as culture, children and youth, the relationship between the employer and the employed, and the poor.

In the I 880 os the Methodist Church still maintained its longstanding hostility with regard to certain art forms, such as dancing and the theatre. Indeed, in I 886 it added what would become, by the first decade of the twentieth century, a highly contentious note to its church discipline, one which forbade 'dancing, playing at games of chance, encouraging lotteries, attending theatres, horse races, circuses, dancing parties, [and] attending dancing schools.' ${ }^{\prime 5}$ At mid-century the Christian Guardian had published an article which described novel reading as 'pernicious' to people as intellectual, social and religious beings. ${ }^{16}$ However, as evidenced by the inclusion of fiction in the Canadian Methodist Magazine, Methodist definitions of what constituted suitable literature had been changing since the I870s. Much in contrast to earlier articles that condemned fiction, the Christian Guardian in February 1879 published a piece, 'Novels and Novel-Reading,' which provocatively 
asked two questions: 'Is there anything essential to this kind of literature that makes it inconsistent with the Christian religion?' and 'Is it sinful or wrong for Christian people, members of Christian churches, to read novels?'I7 Though the proffered response demonstrated a degree of ambivalence, it was a far more favourable assessment of fiction than had previously appeared in the Christian Guardian:

We cannot endorse the extreme view that condemns the reading of all fictitious literature as wrong. No doubt there are grave objections to the prevailing promiscuous reading of sensational fiction. But neither Scripture nor reason would justify the anathematizing of all imaginative literature. ${ }^{\mathrm{I}}$

Moreover, the article acknowledged the prominence of fiction in contemporary society and recognized its potential to mold popular opinion.

Given these facts and conditions, the Methodist Church recognized an obligation to extend its existing bookselling and publishing mandate into the area of fiction; its aim, both sincere and pragmatic, was to provide its membership with a wholesome alternative to the variety of popular, sensationalist, and dangerous fiction that served as a temptation to readers: 'A thoroughly secular and often irreligious literature is being widely diffused, and it is the duty of the Church to provide a literature surcharged with the vitalizing influences of an earnest Christianity.'19

The Methodists' achievement of a national church, and the national perspective and involvement in culture which that accomplishment fostered, helped prepare the way for the church's role in the social gospel. ${ }^{20}$ Indeed, in the late nineteenth century, the Methodist Church emerged as the leading proponent of the social gospel in Canada. A widespread movement in the Western world, the social gospel was connected to the social reform efforts of the late nineteenth and early twentieth centuries. As Richard Allen explains:

The social gospel rested on the premise that Christianity was a social religion, concerned ... with the quality of human relations on this earth. Put in more dramatic terms, it was a call for men to find the meaning of their lives in seeking to realize the Kingdom of God in the very fabric of society. ${ }^{2 I}$ 
By the early I 890 o urban Methodist churches were 'becoming increasingly busy with education, employment bureaus, and relief work among the poor,' and by I 894 the church had established a Committee on Sociological Questions. ${ }^{22}$ In general, the social gospel encouraged the participation of religious bodies in all aspects of life, including those that had previously been designated as secular. The breadth of the Methodist Church's social and national vision found voice in the Christian Guardian in I9I $\mathrm{r}$ :

To the people of Canada has been entrusted a magnificent heritage, with almost limitless possibilities, and only internal strife and mismanagement can check our rapid development. Canadians alone can permanently injure Canada. Racial bitterness must not be fostered upon our soil; religious differences must not be allowed to banish Christian courtesy; political affiliations must be subordinated to patriotic considerations; and the lust of gain must not be permitted to reproduce in Canada the tragedies of European industrial life. The millions of our people are to be welded into one great Canadian nation. This is our work. The task is an herculean one, and the churches of God must lead the way. ${ }^{23}$

\section{Literary and Book Publishing Climate}

A national outlook also came increasingly into play in the literary sphere between 1879 and I9I9. Concern about a national literature was an issue of long standing in Canada, its roots pre-dating Confederation. ${ }^{24}$ In 1858 , for example, statesman and poet Thomas D'Arcy McGee had expounded on the matter, arguing: 'Every country, every nationality, every people, must create and foster a National Literature, if it is their wish to preserve a distinct individuality from other nations. ${ }^{25}$ After Confederation, this concern gained a pre-eminence it had not previously enjoyed. ${ }^{26}$ A national literature was perceived by many at that time as a force that would bind the new dominion together as well as provide tangible evidence that a unique Canadian identity was evolving. Throughout the late nineteenth and early twentieth centuries the Canadian literary community kept its eye out for signs of indigenous literary growth, often bemoaning the apparent slowness of that development and, at times, offering up its own explanations for the sluggish progress of Canadian letters. ${ }^{27}$ Not surprisingly, this concern over the state of the country's literature evoked a feeling of literary 
nationalism among some, leading them to promote and to encourage (at times indiscriminately) Canadian writers and their writing. ${ }^{28}$ Despite this attention to literary nationalism, the Canadian reading public by and large demonstrated a stubborn lack of enthusiasm for Canadian writing before the turn of the century. During the early I 890 s William Wilfred Campbell commented on 'the Canadian contempt and lack of feeling for a Canadian Literature.' Books and Notions in turn linked Canadian disparagement of its own literature to a colonial mentality, stating that 'the Canadian reading public doesn't seem to care for anything until it has first been commended by the book lovers of Great Britain and the United States. ${ }^{29}$ By I 905 , however, the situation showed signs of improvement; that year Bookseller and Stationer remarked on 'an increasing demand for, and appreciation of, the work of Canadian authors. ${ }^{30}$

By the 1890 s Canadian writers of some note had emerged, including Archibald Lampman, Sara Jeannette Duncan, Gilbert Parker, Charles G.D. Roberts, and Edward William Thomson. Indeed, the I 890 s has been identified 'as the first decade of serious literary professionalism' in Canada. ${ }^{3 \mathrm{I}}$ Though the protection provided by a colonial copyright had improved with Great Britain's entry into the Berne Convention in I 886 and the signing of the Anglo-American Copyright Agreement in I891, many of these writers found it advantageous, even necessary, to leave Canada for the publishing centres of Great Britain or the United States, drawn by the better opportunity of remuneration that foreign publication offered and the larger stamp of cultural validation such opportunities provided. ${ }^{32}$

Within Canada, Toronto - now a commercial and cultural centre - formed the nucleus of Canada's English-language publishing industry. Thus, it is not surprising that the Methodist Church's Toronto-based publishing house, rather than the one it operated in Halifax, prevailed as the focal point of the church's publishing operations. That Ontario formed the heartland of Canadian Methodism and Toronto existed as its administrative centre only further worked in the House's favour. Though some books issued during Briggs's stewardship would bear the multiple imprint of William Briggs, S.F. Huestis, and C.W. Coates - Huestis being the Book Steward in Halifax and Coates manager of the House's branch Book Room in Montreal - but for the odd exception, such works do not appear to have been initiated in Halifax or Montreal, rather than Toronto. 
Getting a book published in Canada remained a difficult proposition well into the early twentieth century. Many writers still had to pay the cost of production if they wished to publish in Canada. This practice remained prevalent enough in 1909 to generate commentary in the pages of Canadian Bookman:

There is a custom in Canada ... of authors paying for the publication of their own books. The reason for this can be readily understood. A new and unknown author, unless his or her work is of surpassing merit, naturally cannot find a publisher to take the risk of publication. If the book is to be published, the author must lend a hand and provide at least a part of the money necessary to print and bind the book. ${ }^{33}$

The cost of manufacturing an edition from scratch for the small Canadian market remained a prohibitive proposition for publishers. Foreign competition and copyright remained issues as well. Those publishing houses that did venture into indigenous book publishing usually did so because of the financial stability provided by other aspects of their business. ${ }^{34}$

The gradual shift in Canadian book publishing between 1890 and I 905 from a reprint industry into agency business marked a watershed. ${ }^{35}$ In an agency arrangement, 'essentially the agent agrees to distribute his principal's books in return for a percentage of the profits in the agent's territory, while the principal agrees to refer enquiries from wholesalers and retailers back to the agent.. ${ }^{36}$ Agency agreements did not preclude Canadian publishers from making arrangements for individual titles. With the passing of the I 900 Copyright Amendment, which prohibited the importation of works into Canada for which a Canadian publisher had arranged a local edition, agency business became more prevalent. This amendment encouraged the founding of branch plants in Canada such as Oxford University Press (I904), Macmillan (I905), and Thomas Nelson (1913). ${ }^{37}$ New Canadian publishing houses also emerged, among them University of Toronto Press (I 90I) and McClelland and Goodchild (1906).

\section{General State of the Business}

At its quadrennial meeting in 1878 , the General Conference of the Methodist Church of Canada elected Reverend William Briggs Book 
Steward of its Toronto publishing operation over Samuel Rose and two other candidates. ${ }^{38}$ Briggs succeeded Rose as Book Steward in June I 879, when the latter's term officially ended with the close of the Toronto District's Annual Conference.

Born in Bambridge, County Down, Ireland on 9 September 1836 , Briggs moved with his family to Liverpool, England as a young child. While there he attended the Mount Street Grammar School and later the Collegiate Institute of Liverpool, where he received commercial training. Following his graduation he spent a period of time in commercial life but, finding it uncongenial, he abandoned it to pursue a ministerial calling. In 1859 the Wesleyan British Conference granted him a four-year probationary licence and sent him to Canada. He was ordained in I 863 and afterwards ministered to congregations in a number of communities, the last of them Toronto. During his years with the Toronto Conference he held the positions of Financial Secretary (1874), Chairman of the District (I 876), and Secretary of the Conference (I876-77). At the time of his election to the office of Book Steward, Briggs was 'completing a successful term as minister of . . . the premier pulpit of Canadian Methodism, the Metropolitan Church, Toronto.' 39 His proven administrative abilities and his commercial training made him a good candidate for the position. He arrived at the House with no prior publishing experience but quickly learned the trade and became 'a shrewd and far-sighted bookman. ${ }^{\prime}{ }^{\circ}$ During these years he also served as president of the Toronto Conference (I 885), president of the Masters Printers and Bookbinders Association and, in I90I, was the Canadian representative on the business sub-committee of a Methodist Ecumenical Conference held in England. Victoria University honoured him with a degree of D.D. in 1886.

Briggs was noted for his wit, dedication, and business acumen. One publishing contemporary characterized him as 'the brainiest printer's ink man in the country' whose 'downright good sense and enterprise' made him 'the general of the army. ${ }^{4 \mathrm{I}}$ In I 9 I 3 a journalist reported:

[Dr. Briggs] runs his establishment on the disciplinary menu of an army corps but always with the modifying graces of strict justice and amiability, ... he spurs his people to constant progress and rewards talent and application with promotion, ... [H]e seldom takes a holiday ... but asks no employee to pattern after his example. ${ }^{42}$ 
Briggs's management style encouraged individual initiative among his employees while he maintained a strong guiding hand. Reputedly, every work day began with a conference between him and his department heads. ${ }^{43}$ His tenure was marked by financial success and saw growth in the House's established activities of printing, bookselling, and periodical publication.

Briggs initiated his term as Book Steward with an inaugural address in the pages of the Christian Guardian. In it he set out as objectives running the establishment efficiently and keeping the Book Room well-stocked with good biography, history, poetry, theology, and practical Christianity. He also requested the cooperation of the clergy and laity in making the business a success, emphasizing that the church's printing and publishing concern should not be seen 'simply as a commercial enterprise. It exists, not to make money, but to supply our people with wholesome and instructive religious and literary reading matter, adapted to help them become intelligent and godly workers in the Master's service. ${ }^{\prime 44} \mathrm{He}$ offered no new vision for the church's publishing operation; rather, he reaffirmed the historic espousal that the House's religious imperative must take precedence over commercial considerations.

Financial gains were in evidence in the very first years of Briggs's tenure. At the close of its fiscal year on 3I March I88I, the House registered a net profit of over $\$ \mathrm{r} 8,000$, an amount more than double that of 1879.45 New presses were purchased, and structural changes were made to the House's King Street premises, with alterations undertaken in the retail as well as the manufacturing area of the establishment. On 28 July 1880 the Christian Guardian reported that the Book Room was 'now one of the most pleasant, spacious and convenient book-stores in the city. ${ }^{\prime 46}$ Periodical publication also expanded. By 1883 the House was publishing six Sunday school papers as well as the Christian Guardian and the Canadian Methodist Magazine.

Five years into Briggs's tenure, the I 884 Methodist union took place. This union directly affected the House in two ways: it enlarged the House's Methodist constituency and it augmented its resources. As part of the terms of union, the Methodist Episcopal Church of Canada, the Primitive Methodist Church of Canada, and the Bible Christian Church in Canada were required to pay into the funds of the Methodist Book and Publishing House which, prior to the union, was controlled by the Methodist Church of Canada. ${ }^{47}$ The Book Committee minutes of I 884 note payments from the 
book rooms of both the Primitive Methodist and the Methodist Episcopal Churches in response to this decree.$^{48}$ The terms of union also affirmed the relationship that was to exist between the two centres of publishing (Toronto and Halifax) and the larger church body:

[W] request every minister of the Church to bring before the people among whom he ministers the claims of the connexional publishing houses for their patronage; and that they be solicited especially to subscribe for the periodicals of the Church; also that Superintendents of Circuits use their utmost influence to secure the use of our own Sunday-school periodicals and books in all the schools of our Church. ${ }^{49}$

In the year following union, significant increases were evident in the circulation of the Christian Guardian and the Sunday school papers. The subscription list of the Christian Guardian rose by 2,400 , bringing the paper's total circulation to just over 14,300 . The six Sunday school papers, in turn, registered a growth in subscribers ranging approximately from $I, 750$ to $I 2,450$, with the most popular of them, Pleasant Hours, Berean Leaf Quarterly, and Berean Leaf Monthly, all claiming a circulation greater than 34,000 . That same year the Book Committee determined that $\$ 4,000$ of the House's net profits, an amount double that of the previous year, should be appropriated for the Superannuation Fund, the ministers' retirement fund to which it granted monies annually.

In 1885 Books and Notions ran a lead article on the House. It described its influence as extending from the Atlantic to the Pacific, 'its publications entering the homes of all classes in every portion of our Dominion. ${ }^{50}$ The article also remarked that the House

[maintains] constant communication with all the prominent publishing houses of England, Scotland and the United States, [and] receive[s] soon as issued, all the latest books and do[es] business largely on the cash basis. This puts them in a position to secure the best rates and discounts, as well as to have the newest works in the market with the least possible delay. ${ }^{5 \mathrm{I}}$

Advertisements in Books and Notions that same year provide a list of over thirty British publishers with which the House dealt.

The House's involvement in textbook publishing also buoyed its prosperity. Indeed, along with Copp, Clark, and William Gage, it 'had virtual monopolies in some regions of the country on text- 
books, discounts, and retail prices. ${ }^{52}$ The regulating of school texts by provincial governments in the 1870 s created a lucrative and stable area in the book trade..$^{53}$ During the mid-I 880 s, for example, the Methodist Book and Publishing House, along with W.J. Gage and Copp, Clark, obtained printing contracts from the Ontario government for a textbook series known as the Ontario Readers. These contracts were of ten years' duration and 'ensured the survival of Copp, Clark and Gage, and certainly improved the condition of the Methodist Book and Publishing House, during one of the worst recessions of the nineteenth century. ${ }^{\prime} 4$ The contracts were renewed for another ten years in 1896 . In the late 1890 s the three publishers signed agreements stating they would offer uniform discounts in textbooks. 55

During the late 1880 os the House continued to prosper financially and the circulation of the Sunday school papers remained on the rise. In 1887 the Christian Guardian reported that the House employed one hundred and fifteen people in the manufactory and over thirty clerks in the store, stock rooms, and shipping department. ${ }^{56}$ An employee who worked for the business during this period later remarked that an increase in equipment and lack of space spurred the House's move from King Street: 'The Building was too small for us, and no more alterations could be made, and no more machines added, as the walls and foundations could not stand any more, and business kept on increasing so we had to look for a new home. ${ }^{57}$ In February I 888 the Book Committee resolved to sell the King Street property and move the establishment to Richmond Street; that move was accomplished in September I889. On 2 October I889, the Christian Guardian ran a large advertisement, announcing the House's new location and inviting the public to visit. At that time the House's operations broke down into the following departments: retail, wholesale, subscription book, printing, binding, stereotyping and electroplating, Christian Guardian, and periodicals. ${ }^{58}$

The House's management in the latter half of the I 880 s and I 890 s was marked by a devolution of power and increasing secularization. While there were fewer meetings of the Book Committee in the I 890 s, thus focusing more authority in the hands of the Book Steward, the sheer expansion of the business demanded a diffusion of power within the institution itself. As more departments were created, particular individuals were assigned the task of running them. These individuals were not members of the clergy and, thus, greater secular input occurred. As a business technique, the 
aim of decentralization was to strengthen executive accountability in the large organization. A big company could overwhelm even its own management when the performance of its components got lost in the work of the whole. Under departmentalization the men at the top could study the health of the parts one at a time, accurately pinpointing trouble spots. Similarly, each of the subordinate managers, now literally accountable for the performance of his department, could be held personally responsible for success or failure. ${ }^{59}$

Briggs's use of departmentalization and his encouragement of individual initiative paralleled the practices of such Methodist businessmen as Joseph Flavelle and H.H. Fudger. Michael Bliss explains that 'Flavelle and businessmen like him were committed to individualism. ${ }^{60}$ That commitment was consistent with early Methodism's emphasis on individual responsibility and endeavour. However, it also reflected Protestant Ontario's faith in the power of individuals to affect their world. ${ }^{61}$ Indeed, many successful businessman believed 'they owed their success' to following a life of 'thrift, sobriety, and hard work' - 'Protestant' values that crossed both denominational and class lines. ${ }^{62}$

Not content to depend solely on ministers, lay persons, and canvassers to act as agents for the House, Briggs began to hire people to serve in this capacity. As early as 1885 the House had hired its first regular traveller, C.W. Small. By I 890 John A. Solomon was managing the wholesale department and actively purchasing for the House, a responsibility formerly undertaken by the Book Steward. ${ }^{63}$ In 1890 both Books and Notions and the Book Committee Report to the General Conference revealed that a number of travellers were at work on behalf of the institution. ${ }^{64}$ The latter argued that their activities would aid the House's religious imperative:

Under the feeling of duty to spread as widely as possible the periodical and other literature of the Church as well as what is healthy and useful in the publications of other Houses, a still more aggressive policy has been adopted. Not only have the established agencies of the Church been kept in use, but every corner of the land has been visited by special agents to extend the trade. ${ }^{65}$

Rhetoric aside, this was an important statement. From one perspective the House's adoption of a 'more aggressive policy' may be viewed quite simply as the natural impetus of a financially healthy business toward expansion. However, it must also be connected to 
the Methodists' national and social gospel impulses. The House's determination to extend its reach beyond the Methodist community into the larger society was in keeping with the church's ambition to effect positive changes in Canada's cultural and social life.

During the 1890 s the Methodist Church's interests were clearly evident in the House's Sunday school periodicals. In 1890 the Book Committee resolved to launch Onward, a Sunday school paper directed toward senior classes and the Epworth League. ${ }^{66}$ The Epworth League, a Methodist youth group, had been organized in I889 and reflected the church's growing focus on youth. ${ }^{67}$ The House later dedicated a paper to it specifically. Among other things, the league canvassed for the House and promoted a strongly nationalistic course of readings which 'included heavy doses of Canadian literature, scientific discoveries, development of the Empire, and the lives of famous Canadian and British statesman, explorers and missionaries. ${ }^{68}$ Also of interest is the Toronto Annual Conference's I 892 recommendation that the church's Sunday school papers should embody 'loyal sentiments.' To this suggestion the Book Committee responded:

With regard to the recommendations of the Toronto Conference respecting our S.S. [Sunday school] periodicals being loyal to our country, we deem no special action of this committee necessary, as we are satisfied that Dr. Withrow will edit these papers in harmony with the spirit of these recommendations. ${ }^{69}$

Withrow, who edited the Sunday school papers as well as the Canadian Methodist Magazine, held nationalist and imperialist sentiments sympathetic with those of his church. In a letter to William Kirby in 1904, he explicitly stated that he had been promoting the 'closer federation of the empire' in recent numbers of Onward. $7^{\circ}$. Thus, these periodicals served as vehicles for the church's particular brand of nationalist and imperialist propaganda. $^{7 \mathrm{I}}$

Despite a depression that maintained a grip on the economy through most of the I 890 os, the Methodist Book and Publishing House prospered during this decade. Though increases were likely driven in part by a growing number of retired ministers, ${ }^{72}$ a measure of that prosperity emerges from the record of annual appropriations to the Superannuation Fund: in I891 \$6,500 was given over to the fund, in I $895 \$ 7,500$, and in $1898 \$ 10,000$. However, the occasional 
stress of an ideological or financial nature was also evident. Despite similar tactics adopted by Samuel Rose in the I870s, Briggs's I 892 promotional effort of offering prizes to new subscribers created some anxiety among the members of the Book Committee, compelling him to explain to them 'that there was nothing of the nature of a lottery in these prizes. ${ }^{73}$ The problem of ministers' overdue accounts, which had proved troublesome through the House's first fifty years, also persisted, leading the Book Committee in I893 to authorize the Book Steward to 'use such means as he could to procure a large reduction of that indebtedness. ${ }^{74}$

Finding the sale of trade books a lucrative activity, Briggs concentrated more attention in this area. ${ }^{75}$ The church's shifting attitude toward literature gave the pursuit of trade book sales a sanction and viability it had not previously enjoyed. After I 894 Briggs

turned the firm into the Canadian agency of many New York and London houses, the most important of which were the Religious Tract Society, Thomas Nelson, Blackie, Oliphant, the Chatauqua Library and Scientific Circle, G.P. Putnam, and the popular Pansy Books written by Annie Swan and Mrs. G.R. Alden. ${ }^{76}$

The company also began to negotiate with authors or their publishers for Canadian editions of specific titles. These activities anticipated the general direction of Canadian book publishing after the turn of the century. One of Briggs's more intriguing agency arrangements was with the Wood-Allen Publishing Company; he distributed its 'Self and Sex Series' -- the series included monographs addressing the sexuality of individuals at various stages in their lives - under the advertising banner of 'Pure Books on Avoided Subjects. ${ }^{77}$

With the passing of the I900 Copyright Amendment, the House moved more fully into large-scale agency publishing. ${ }^{78}$ Competing publishers, such as Musson, McLeod and Allen, McClelland and Goodchild, Macmillan, and Copp, Clark, were similarly engaged. ${ }^{79}$ Canadian publishers also arranged contracts for individual titles. An average Canadian edition would consist of $I, 000$ or I, 500 copies; however, larger editions would be produced for bestselling authors. Briggs negotiated for works by such popular writers as Marie Corelli, S.R. Crockett, Mrs. Humphrey Ward, and Arthur Conan Doyle. ${ }^{80} \mathrm{~A}$ first edition might consist of six thousand copies for these writers. In the case of Marie Corelli's God's Good Man, the House printed ro,000 copies 'within a year of its publication, and did almost as 
well with Treasure of Heaven and Holy Orders at a time when 4,000 copies was considered a good sale for a novel in Canada. ${ }^{81}$ (Average sales for a novel were usually well under 2,000 copies. $\left.\right|^{82}$ Between I 899 and I9I 8 many foreign-authored bestsellers appeared under Briggs's imprint in Canada. ${ }^{83}$

Annual appropriations to the Superannuation Fund increased steadily over the first thirteen years of the twentieth century, peaking at \$23,000 in I9I2. Profits were down somewhat in 1902 because of higher wages, the imposition of postage on periodicals previously carried free, and increased competition. ${ }^{84}$ The Book Committee minutes of 1900 had decried heavy postage on religious and Sunday School periodicals as they had

no revenue from advertising [this was not the case for the Christian Guardian] and receive keen competition from American papers which come into the country free of duty, whereas printing presses, type, paper, ink, everything which enters into the cost of Canadian papers, pay a heavy duty. ${ }^{85}$

The Christian Guardian's circulation was also a concern and articles encouraging new subscribers appeared regularly in the paper. ${ }^{86}$ Much in contrast to Samuel Rose's offer in the 1870 s to procure for a customer any book suitable to the House's stock, ${ }^{87}$ by 1905 the House advertised:

We can supply you with any book you want, no matter what the subject or where published. A large and well assorted stock of the best books of the various publishing houses is kept constantly on hand, and our unequalled arrangements enable us to secure any book not carried in stock that is yet in print. ${ }^{88}$

In 1906 the Book Committee reported to the General Conference that the 'past four years have not been remarkable for any very striking feature, but have witnessed a steady growth which has carried us to a point where our present premises and facilities are taxed to the utmost. ${ }^{89}$ Additions were undertaken. In May 1909 the House won an important five-year printing and binding contract with the Ontario government; it continued to do the government's printing for at least a year after the contract's formal expiration in June I9I $4 .{ }^{9 \circ}$ By I 913 the House's 'total business' consisted of 52 per cent manufacturing, 25 per cent wholesale trade, 16 per cent periodicals, $\mathrm{I} / 2$ per cent mail order, 2 per cent retail, and $\mathrm{I} / 2$ per cent office rental..$^{9 \mathrm{I}}$ 
As early as I9I I the Book Committee had begun discussing another relocation, and by I9I 2 debentures were being sold to the Methodist community to help finance the proposed 'million

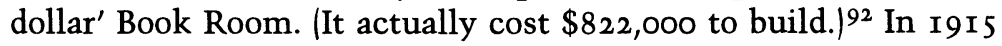
the House moved to a newly constructed five-storey building on Queen and John Streets. Envisioning future growth, the new building was constructed with foundations strong enough to support another five storeys if they came to be required. ${ }^{93}$ Consistent with prevailing Methodist social gospel interests, the building also provided a better physical working environment for the House's employees. 94

In the early twentieth century tension between the House's religious imperative and its commercial impulse could not be avoided on several occasions. In 1900 a resolution of the Toronto Conference favouring free distribution of religious tracts and cheap books in mining and lumber camps came before the Book Committee. The committee rejected the proposal, stating that such works could only be supplied at cost; it emphasized not only that the House had no funds dedicated to the purpose of freely distributing publications but also that it did not seek donations for such activities in the manner of the tract societies. 95 Clearly, the Book Committee did not see the House as a charitable organization. Nor was its position on this matter inconsistent with earlier judgements; throughout the House's history the Book Committee had erred on the side of financial caution in its publishing decisions.

Three further incidents of conflict between religious and commercial considerations arose during the next fifteen years. In I90I Reverend Egerton Ryerson Young, Sr. wrote to the General Superintendent of the Methodist Church to express his disapproval about the nature of the literature being disseminated by the House. The Book Committee, to whom the letter was forwarded, concluded that the Book Steward had taken every reasonable care and affirmed its 'confidence in the ability of Dr. Briggs to so conduct the business as to reflect credit upon the connexion. ${ }^{\prime 96}$ Eleven years later the Toronto Public Library rejected two unnamed books of light literature issued by the Methodist Book and Publishing House as unfit for public reading. The Toronto World reported:

[T] he announcement [of the Toronto Public Library] caused some consternation at the book room when the news reached there, as the tone of the fiction published there has been under hot fire at several of the Methodist Conferences. 
It has also transpired that some of the books for which a Yongestreet re[t]ailer was fined for offering for sale were from the Methodist Book Room. They happened to have been seized there before they were prominently displayed at the book room store. ${ }^{97}$

The Evening Telegram, in turn, reported that Briggs had been unwilling to comment on the incident. One of Briggs's ministerial colleagues, however, expressed his support for the Book Steward, saying that 'if any such books did slip through it was certainly not by consent or knowledge of Dr. Briggs' and cited occasions when Briggs had, at a loss to the House, returned plates 'in order to preserve the cleanliness of the publications. ${ }^{98}$ Certainly, this claim finds support in Briggs's 1905 contract for H. Rider Haggard's Ayesha, which included a clause that allowed Briggs to withdraw from the agreement if the book contained anything blasphemous or immoral. ${ }^{99}$ When the issue arose at the Book Committee's annual meeting in May I9I 2, the minutes recorded that the Book Steward had offered a rebuttal satisfactory to the committee without providing any details. ${ }^{100}$ Either Briggs was incredibly persuasive in his response or the committee was only paying lip service to the issue.

A third scandal arose in 191 3 over the purchase of the Queen and John Street property. The sellers of the property had close connections with the House; after a special investigation they, along with Briggs and his assistant, were exourated of any wrongdoing. ${ }^{\text {IOI }}$ The scandal provoked some interesting commentary on the nature of the church's publishing house. Even prior to it concern had been expressed about the purchase; one individual wrote to the Christian Guardian: 'For purely factory purposes the new site is well chosen. For Book Room and office purposes it is an absurdity. ${ }^{102}$ The new property was in the factory rather than the retail district of Toronto; its choice reflected the fact that the House's manufacturing activity generated twenty-six times the business of its retail operation. Subsequent to the inquiry Ernest Thomas, who by I92I would be a member of the church's Evangelism and Social Service Department, also wrote to the Christian Guardian; he pointed out that the House had been initiated in order 'to facilitate the mission of the church' but that ' $[\mathrm{g}] \mathrm{radually}$ manufacturing, which was incidental to the mission of the church, became itself the chief end of the business. ${ }^{103}$ While acknowledging 'that in asserting the priority of this manufacturing and commercial interest the committee is following in the established path of our recent development,' he questioned whether the church was 'morally justified' in the policy 
it had adopted. ${ }^{104}$ His query was applauded by a third writer who went on to argue:

I may be mistaken but I have the impression that our Book Room has been commending itself of late years largely by its contribution to the Superannuation Fund. It has not been commending itself by supplying the libraries of ministers and colleges with books at the lowest possible rates. That interest has been quite subsidiary. It has not been commending itself by the circulation of only such books as will promote the best kind of religious culture. It is time for us to review our policy on the management of the Book Room and harmonize it with the spiritual function of the Church. ${ }^{\text {IO5 }}$

Formerly the House's business prosperity had found justification in the belief of John Wesley, the founder of Methodism, that business was a legitimate Christian calling and that prosperity was the by-product of the hard work and frugality of a godly life. ${ }^{106} \mathrm{How}$ ever, as the church's own perspective developed a greater social consciousness and the validity of the commercial impulse came under examination, the activities of its publishing house were subject to questioning.

Ironically, the church's support of Canada's involvement in the First World War proved beneficial to the House's commercial impulse. With the declaration of war 'there was a run on books dealing with Germany and the Great Powers, the events leading up to the outbreak of hostilities, the comparative military and naval strength of the combatants, and the leading soldiers and statesmen on both sides. ${ }^{107}$ Like its competitors, the House took advantage of this phenomenon and disseminated many such books. ${ }^{108}$ The church's support of the allied war effort sanctioned that pursuit. Even so, one suspects that such blatantly sensational advertising copy as '[y]our library will not be complete without the literature of these strife-torn years upon its shelves. We offer you of the best. Grasp the opportunity'109 provoked a shudder from some members of the Methodist community.

In the final five years of Briggs's tenure the House faced a number of setbacks. First, in December I9I4, Reverend J.J. Redditt, the assistant Book Steward, died. Redditt, who had served as Briggs's assistant for seven years, had represented the House at association meetings and had been much involved in the planning and construction of the new building on Queen and John Streets. ${ }^{\text {IIO }}$ His death removed an active and able individual. The following May the 
Montreal Book Room was closed because it had generated a large deficit for the previous fiscal year and showed 'no probability of ... ever being financially successful. ${ }^{\text {III }}$

In general, the Book Committee minutes of I9I5 through I9I 8 cite trade and war conditions as negatively affecting the House's finances. Briggs made a personal appeal in the Christian Guardian in 1917 , noting the 'great advance in the cost of paper, inks, and all other paper used in the publishing business' as a source of difficulty and requesting that the House's patrons settle their unpaid accounts. ${ }^{\text {II } 2}$ That same year a portion of the debentures issued in I9I4 came due; a second series of debentures was hurriedly issued and creatively marketed through a series of advertisements. In I9I 8 the House cited growing jusiness expenses, with wages rising by $\$ 31,000$ and material costs increasing by $\$ 55,000 .{ }^{113}$ Another Toronto-based publisher, The Westminster Company, recorded similar troubles: its shareholder meeting of 27 March 1918 reported a 55 per cent increase in printing costs and a 33 per cent increase in paper costs over the previous year. ${ }^{\mathrm{II} 4}$ The House also faced staffing shortages, as over Ioo of its 350 employees (approximately 29 per cent) had gone to war. ${ }^{\text {II }}$ The House's appropriation to the Superannuation Fund dropped from $\$ 23,000$ in I91 6 to $\$ 20,000$ in 1917 , then down to $\$ 15,000$ in I918, before increasing to $\$ 22,000$ in I919. Finally, efforts to sell the old Richmond street property were in abeyance until the real estate market improved. ${ }^{116}$ Despite these setbacks, the Book Committee remained supportive of William Briggs and his endeavours, regularly recording its praise of him in the Book Committee minutes during the later years of his stewardship. When his successor, Samuel Fallis, was chosen at the General Conference of 1918 , the cuaference conferred upon Briggs the title of Book Steward Emeritus, granted him a retiring allowance of $\$ 2,000$ annually and offered him its deepest appreciation:

[I]n view of the retirement of Rev. William Briggs, D.D., from his present position at the next Annual Conference, this General Conference offers to him its most earnest expression of profound gratitude for the long and distinguished service rendered to the whole Methodist Church in the capacity of Book Steward. Receiving, as he did at the time of his appointment, a small concern, he has built up for us one of the strongest book and publishing businesses in Canada. He has made the Methodist Book Room a household name throughout our connexion and Canada. He has put his whole life and soul into this enterprise, and the virtues and honor of his own 
heart are capitalized for all future generations of Methodists in Canada, in this institution which he has so signally served. ${ }^{\mathrm{II}}$

Briggs's retirement took effect in June r9I9 after the close of the Toronto District Annual Conference. However, as the designated Book Steward Emeritus he maintained an office at the House until his death on 5 November 1922.

\section{Key Individuals}

In considering the state of the House's book publishing and its commitment to Canadian writing between 1879 and 1919, it is important to recognize the presence of a number of individuals who were associated with the institution. Each had a role to play, though it is difficult to state categorically the extent of each's influence.

The I 878 General Conference that elected William Briggs Book Steward also returned the Reverends Edward Hartley Dewart (I 828I903) and William Henry Withrow (I839-1908) to their positions as Editors of the Christian Guardian and the periodicals respectively. Described by Lorne Pierce as 'the great triumvirate, ${ }^{\prime 1}{ }^{18}$ until Dewart's retirement from the Christian Guardian in I894, these three men spent fifteen uninterrupted years together as the officials of the House and fellow members of the Book Committee.

Born in Stradone, County Cavan, Ireland on 30 March I 828, E.H. Dewart came to Canada at the age of six. He spent the remainder of his childhood in Peterborough County, then attended the Toronto Normal School. After teaching a year in Dunnville, he entered the Methodist ministry on trial in $185 \mathrm{I}$, was ordained in 1855 , and then served congregations in both Canada East and Canada West. The Conference elected him to the Christian Guardian's editorship in I 869 .

Dewart, it appears, did not have a direct editorial hand in the House's book publishing during Briggs's tenure. The Christian Guardian likely absorbed all his energies; by the I870s his work as Editor had grown to the extent that an assistant editor had been assigned to him. Nevertheless, his influence needs to be acknowledged: he not only held sway as a publishing house official and a member of the Book Committee but also arrived at the House with a personal commitment to Canadian writing. In his Selections from Canadian Poets ( 1864 ) his objective had been 'to rescue from oblivion some of the floating pieces of Canadian authorship worthy 
of preservation in a more permanent form; and to direct the attention of my fellow-countrymen to the claims of Canadian poetry.' ${ }^{\prime 19}$ The introduction to his anthology provides important insights into the literary climate of his day. He not only remarked on an 'almost universal absence of interest and faith in all indigenous literary productions' and described the colonial position as unfavourable 'to the growth of an indigenous literature' but also expressed his own faith in Canada's ability to inspire poetry. ${ }^{120} \mathrm{He}$ reiterated these ideas in the pages of the Christian Guardian during the 1880 s. $^{121}$ Most pertinently, Selections from Canadian Poets set out Dewart's belief in the importance of a national literature:

Equally shallow and reprehensible is the idea, very widely entertained that, because we can procure sufficient quantities of mental aliment from other lands, it is superfluous to make any attempt to build up a literature of our own. A national literature is an essential element in the formation of national character. It is not merely the record of a country's mental progress: it is the expression of its intellectual life, the bond of national unity, and the guide of national energy. ${ }^{\text {.22 }}$

Dewart's sentiments echoed those of Thomas D'Arcy McGee. The idea that 'literature was by definition the expression of a nation' formed the cornerstone of Canadian literary criticism well into the twentieth century. ${ }^{123}$ During the remainder of his life, Dewart published one book of his own original verse, Songs of Life (I 869), a collection of essays, and a number of pamphlets on religious subjects.

Like Dewart, W.H. Withrow was a writer in his own right. Born in Toronto on 6 August 1839 , he was educated at the Toronto Academy and later attended the University of Toronto and Victoria University. He received an M.A. in I865. After being admitted to the ministry in 1866 , he served several congregations, then taught mathematics, logic, and metaphysics at the Wesleyan College, Hamilton. ${ }^{\mathrm{I} 4}$ Before joining the House, Withrow published articles in the Methodist Quarterly Review and wrote a book entitled The Catacombs of Rome and Their Testimony Relative to Primitive Christianity (1 874). Both the journal and his book were issued by the American Methodist Book Concern. ${ }^{125}$ The Catacombs of Rome received favourable reviews; by 1907 it was in its sixth edition in Great Britain and enjoyed a wide circulation in North America. ${ }^{126}$ 
Withrow garnered a great deal of respect from his contemporaries. He was honoured with a D.D. from Victoria University in 1880 and elected to the Royal Society of Canada in 1884 . Rev. S.S. Nelles, principal of Victoria University, wrote Withrow in I87I: 'I fully expect you to distinguish yourself. You have a talent for writing and should nurse your genius. ${ }^{127}$ In 1885 Books and Notions commented on Withrow's 'name and fame as an author,' opining that the fact that he edited the Canadian Methodist Magazine and Sunday school periodicals was 'a sufficient guarantee of their merit. ${ }^{\prime 28} \mathrm{He}$ also held honorary memberships in the Woman's Canadian Historical Society and the Society of Canadian Literature.

Although Withrow was appointed as assistant editor of the Christian Guardian in I 874, the Book Committee quickly redirected his energies toward editing the Canadian Methodist Magazine and the Sunday school papers. He wrote prolifically, contributing both to the magazine and the Sunday school periodicals as well as producing other work. His efforts include biography, travel, fiction, and history. In his letters to William Kirby, however, he reveals frustration. 'My own time is frittered away in chips \& shavings for daily use,' he wrote in the early 1880 s and later: 'I am grinding away in the mill in routine work that absorbs all my time. While it is not very high art I believe it is very useful and successful \& I am trying to serve my generation to the best of my humble abilities. ${ }^{129}$

As revealed by his first editorial in the Canadian Methodist Magazine, Withrow felt a deep commitment to Canadian writing. A great admirer of Kirby's work, he offered the author both advice and assistance in getting The Golden Dog published and even quoted Kirby's poetry in one of his novels. ${ }^{130}$ In a review in $\mathrm{I} 888$ Withrow challenged those who argued that Canada did not possess a native literature:

There are those who say that Canada has no native poetry, and indeed, little native literature of any sort. They seem to think that as a people we are so rough, raw, and uncultivated, so engaged in the sordid race for riches, if not indeed in a mere struggle for existence, that we have neither time nor taste to cultivate the gentler muse. The annexed list of books ... disproves this unjust and unpatriotic assertion.... For so young a country, for a country so handicapped in the literary race, for a country where our native poets are brought into rivalry with the most cultured singers of old and wealthy civilizations, we think that their efforts are something of which we may well be proud, are auguries of higher achievements 
in the future, and merit the kindly patronage of those who would foster a love of poetry, both for its own sake and as an important element in our native literature. ${ }^{\text {I3 I }}$

The ensuing article discusses work by George Frederick Cameron, William Wye Smith, and W.D. Lighthall. Both Smith and Lighthall merited praise for offering a number of poems on Canadian themes; Withrow felt this indicative of 'a growth of national sentiment' and of 'a pulse of Canadian patriotism throbbing in the hearts of our native writers. ${ }^{\prime 32}$ Thus, the progress of Canadian letters became a measure of the country's development of a unique identity and its citizens' response to it.

In his capacity as Editor of the periodicals, Withrow encouraged and actively sought out Canadian writers. ${ }^{133}$ His editorial responsibilities also extended into the area of book publishing though his job title did not indicate this was a part of his duties. Lorne Pierce has highlighted Withrow's role in the House's book publishing as follows:

Through his Magazine he brought to the House most of the outstanding names in Canadian letters of his day. He was in a very real sense Book Editor of the Publishing House, and may reasonably be regarded as the founder of the Book Editorial Department. ... He made the House incomparably the leading publisher of Canadian books of his time. ${ }^{\mathrm{I}} 34$

While Withrow's role in drawing Canadian writing talent to the House and encouraging the publication of books should not be underestimated, Pierce's opinion is an oversimplification. It considers neither the environment surrounding the House during these years nor the importance of certain employees at work within the institution. Those who headed up the book publishing and wholesale departments during Briggs's tenure deserve particular note: E.S. Caswell, F.S. Ewens, E.J. Moore, S.B. Gundy, and E.W. Walker.

Edward S. Caswell (I 86I-1938) joined the House in I 881; initially he was a member of the printing department, where he did proofreading and compositing work, but by 1892 he had charge of the book publishing department. ${ }^{\mathrm{I}}{ }^{35}$ In the latter capacity he read manuscripts, corresponded with authors, provided editorial advice, collected reviews, and promoted the books once issued.

Born in Goderich, Ontario in I86I, Caswell was the son of a Methodist minister. As a young man he spent three years on the 
staff of the Lucknow Sentinel and contributed articles to it in later years. Active in the Toronto community, Caswell was a founding member of the Canadian Club (est. I 897), founder of the Broadway Debating Club, an historian for the York Pioneer and Historical Society, and an energetic lay member of the Methodist Church. He compiled a small collection of autograph poems by Canadian writers, Canadian Singers and their Songs, which he published with the Methodist Book and Publishing House in I902. Two subsequent and enlarged editions of this work were published by McClelland and Stewart in 1919 and 1925 . He also edited McClelland and Stewart's 1929 edition (the first Canadian edition) of Catharine Parr Traill's The Backwoods of Canada.

During his years as manager Caswell reached out into the literary community and attracted a number of important authors to the House, among them Catharine Parr Traill and William Wilfred Campbell. ${ }^{136}$ Writing to the former author in $\mathrm{I} 897$, he expressed a deep commitment to his work at the House: 'As time goes on my work here seems to grow more engrossing. I seem to live in it and for it - as well as by it. The increasing number of our publications brings increasing duties, and it ties me up pretty closely, body $\&$ brain. ${ }^{137}$ As an individual, he commanded much respect from the literary community of his day. One of his contemporaries acknowledged him as '[o]ne of the best living authorities on Canadian literature,' and Bookseller and Stationer deemed that he could 'qualify as the patron saint of many struggling Canadian authors. ${ }^{138}$ When he left the House in 1909 to join the Toronto Public Library, Saturday Night noted that Caswell had devoted much energy and talent to the company and that he had no little share in making the institution over which Dr. Briggs presides a great publishing house.' ${ }^{\prime 39}$ Canadian Bookman, in turn, expressed approval of the library's decision to hire Caswell:

The appointment of Edward S. Caswell of the Methodist Book and Publishing House of Toronto, to be assistant librarian at the new Public Library, has met with universal approval. It has been felt that no better choice could have been made. . . He has had personal charge of the publication of many notable Canadian books, and in this way has made the acquaintance of a wide circle of authors, and has familiarized himself with Canadian literature, as few others have had an opportunity to do. He is thus admirably qualified to assume the duties of his new position, where he will work under ideal conditions. ${ }^{140}$ 
Caswell left the House 'followed by the esteem and best wishes of every official and employee. ${ }^{14 \mathrm{I}}$ His new appointment raised his status in the church's eyes, and, by 1920 , he was exerting his influence once again as a lay member of the Book Committee, a position he never could have aspired to as an employee of the House.

To his new employer, George H. Locke, who had been appointed chief librarian of the Toronto Public Library that spring, Caswell was likely an appealing choice for two reasons: first, because he was a fellow Methodist and, thus, had been inculcated with beliefs similar to those held by Locke; and, secondly, because Caswell had knowledge of Canadian writing and was active within the Toronto literary community. Locke and Caswell knew one another prior to the latter's appointment; indeed, Caswell's appointment only confirms the Methodist connections at work within Toronto's close-knit business and cultural community near the turn of the century. ${ }^{\mathrm{I} 42}$ (Such connections had probably attracted to the House printing business from both Timothy Eaton and the Methodist coterie that purchased the Robert Simpson Company in I 898. $\left.\right|^{143}$ Caswell's involvement in Canadian letters would also have been important as the chief librarian himself had an interest in indigenous literature; during his librarianship, Locke would oversee the compilation of numerous contributions to Canadian bibliography. ${ }^{144}$ One may only speculate about Caswell's involvements in these efforts as, after his move to the library, he seems to have been overshadowed by the highly visible Locke.

Indeed, for a man who merited such respect from his contemporaries, frustratingly little documentation of Caswell's thoughts about and contributions to Canadian literature appears to have survived. In 1907 Caswell did publish an article, 'Canadian Books for Canadian Readers,' in which he discussed the slow emergence of faith in the country's writers by the Canadian public and Canadian academics. He also criticized the lacklustre efforts of booksellers in promoting Canadian writing. ${ }^{145}$ Some of Caswell's opinions also find voice in a letter to the Canadian Magazine in April I9I 3. In February of that year the magazine had published an article, 'A Decade of Canadian Poetry,' by J.D. Logan. Writing in response to this piece, Caswell was willing to accede to Logan's point that Canadians showed more concern for material things than anything else, but Caswell saw that absorption as inevitable in a sparsely populated and developing country. He also expressed surprise at the omission of such poets as Isabella Valancy Crawford and Alexander McLachlan from Logan's discussion and could not accept his assess- 
ment of Robert W. Service's verse as vulgar and abominable. ${ }^{146}$

Caswell's most expansive discussion on the subject of Canadian literature appeared in the Christian Guardian in 1909. After pointedly acknowledging that a 'few observations on the subject of Canadian literature . . . may provoke a cynical smile from any of the high apostles of Literature (always with the capital L),' Caswell launched into its defence. He argued that Canadian writers, given the country's population, had produced a creditable number of meritorious books. Like many of his contemporaries, he saw both the country's colonial past and the 'practical work of hewing homes' from out of the forests as having inhibited indigenous literary growth. His own publishing experience also informed his argument:

We looked to the Mother Country and the United States for the supply of books which could not be brought out here. The most of our cultured class of readers came originally from the older countries, and naturally turned to them for their supply of reading matter. Our authors looked in vain for the support and encouragement they should have had. Publishers were cautious, not to say timid, and booksellers were indifferent. ${ }^{\mathrm{I}}{ }$

Interest in Canadian literature, he felt, began to strengthen in the I890s; 'the growth of the population and the development of a national spirit' were the source of that change. ${ }^{\text {I48 }}$ As a result indigenous authors and publishers gained credibility, the newly created public libraries began to stock Canadian books, and Canadian publishers became more venturesome with respect to native writers. ${ }^{149}$ In the end, however, the greatest source of information about Caswell's feelings toward Canadian literature emerges from his letters; his correspondence reveals him as a man who was committed to nurturing Canadian writing and to promoting the work of individual writers.

F. Sidney Ewens (I 872-I9 I4) succeeded Caswell as manager of the book publishing department in 1909. He had joined the House in I 885 as a printer's apprentice and by 1908 was managing the newly created publicity department. ${ }^{.50}$ During these years he was closely associated with Caswell, with whom he shared similar views. ${ }^{\text {I5 I }}$ His colleagues considered him a good judge of the literary and commercial possibilities of a manuscript. ${ }^{152} \mathrm{He}$ had been managing the book publishing department for four years when he died on 5 January I9I4. Caswell saw Ewens's death as a 'distinct loss to Canadian literature' while Bookseller and Stationer wrote of him: 
$[\mathrm{H}] \mathrm{e}$ was considered not only as a business acquaintance, but as a personal friend by a great many authors of recent Canadian books. To his encouragement and personal interest are due the bringing out of many volumes which would otherwise never have seen the light of publicity. . . . It was a frequent thing for university professors, magazine editors and others who wanted information regarding some Canadian book or author to refer to him, and the desired information was almost without exception forthcoming. ${ }^{\text {I }} 53$

E.J. Moore (I88I-I96I), who joined the House in I9I4, assumed the role of manager of the book publishing department after Ewens's death. Born in Acton, Ontario on I November I 88I, Moore received his early education there and subsequently attended Georgetown High School, Albert College in Belleville, and Victoria University. His father, H.P. Moore, was the editor of the Acton Free Press and a lay member of both the Book Committee and the Joint Union Committee. His uncle, Reverend T. Albert Moore, held prominent positions within the Methodist Church, including Secretary of the General Conference and Secretary of the Temperance and Moral Reform Committee.

As a youth Moore apprenticed in his father's printing office. He later pursued journalism in Toronto, contributed to Sunday school papers, and did editorial work for both the Canadian Grocer and the Pioneer. As manager of the House's book publishing department, however, he demonstrated poor editorial and proofreading skills and questionable judgment with respect to manuscripts. In the I 920 s both William Arthur Deacon and E.J. Pratt would express their disgust with Moore, the former identifying him as a reason for the House's loss of prestige in the years immediately preceding Lorne Pierce's arrival in $1920 .{ }^{154}$

Samuel Bradley Gundy (I870-1936) was another important figure involved in the House's book publishing. Like Caswell, he was the son of a Methodist minister. Born in Aurora, he moved with his parents to Toronto as a young child and was educated at the Ryerson School. During his life, he held memberships in a number of clubs and organizations, including the Canadian Club (Toronto), the National, and the Arts and Letters Club. He was also instrumental in the founding of the Canadian Chamber of Commerce.

Gundy's career in publishing began in r 884 when, at the age of fourteen, W.J. Gage \& Company hired him as a junior clerk. Four years later the company sent him out as a traveller. In I893, when he was twenty-three years old, he moved to the Methodist Book and 
Publishing House where he took on the management of its wholesale department. During his years there, he travelled extensively throughout Canada and took regular trips to Great Britain and the United States to make arrangements with publishers and authors in those two countries. The trade book aspect of the House expanded under his management, and Bookseller and Stationer praised him for 'rapidly developing the output of the house in high-class fiction.' ${ }^{\prime 55}$ His contemporaries considered him an able bookman with a special gift for gauging the sales potential of individual works.

In 1904 Oxford University Press of London asked Gundy to manage the Canadian branch it was about to open in Toronto. Oxford offered him a 'free hand to develop the business,' a large salary, and a share of profits. ${ }^{156}$ Gundy accepted, writing Briggs of his decision in January 1904:

The past eleven years have been full of pleasure \& my memory recalls only kind thoughts $\&$ considerate treatment at your hands. It is however only to[o] true that I have 'reached the limit' in my present position. You have done everything possible and in justice to myself I must make the change. ${ }^{157}$

Gundy's words highlight an important aspect of the Methodist Book and Publishing House's structure. No employee of the House could ever progress beyond the management of a department; the official and most prestigious positions within the institution - those of Book Steward and Editors of the Christian Guardian and the periodicals - were reserved for Methodist clergy. Neither did department heads serve on the Book Committee; their presence at these meetings was rare and such appearances had to be sanctioned by the committee. Thus, though the House nurtured a great deal of management talent, it could not exploit the full potential of such individuals. During the course of Briggs's stewardship, S.B. Gundy, John McClelland, Thomas Allen, Frederick Goodchild, and George Stewart all left the House's employ to strike out on their own; they became prominent members of the Toronto publishing scene in the early twentieth century. The substantial increases in managerial salaries which occurred after Gundy resigned suggests that Briggs was well aware of his managers' contributions. ${ }^{158}$

With Gundy's departure, Ernest W. Walker (b. 1874) took on the management of the wholesale department. Walker began his employment with the House in 1892 , and by 1893 he was the 
House's Maritime traveller. ${ }^{159}$ Like Gundy before him, Walker travelled extensively and negotiated with British and American publishers for the right to sell or publish their titles in Canada. By I9I9 he had under his direction four other travellers. ${ }^{160}$ His comments on trade conditions also appeared periodically in the pages of Bookseller and Stationer.

Walker's employment with the House endured into the I940s; according to one who knew him at that time, he was shrewd and competent in his work and well respected by the English and American publishers with whom he dealt. ${ }^{\mathrm{I}}{ }^{\mathrm{I}} \mathrm{H}$ However, in the early twentieth century he lacked the vision that characterized Gundy's work, was loathe to take risks, and frustrated first Caswell, and later, Lorne Pierce in their efforts to promote Canadian literature.

\section{Conclusion}

The heavy emphasis which has traditionally been placed on William Briggs as the force behind the Methodist Book and Publishing House's commitment to publishing Canadain-authored titles in the late nineteenth and early twentieth centuries has left unexplored and unacknowledged both individuals and circumstances which made an impact on that endeavour. E.H. Dewart, W.H. Withrow, E.S. Caswell, F.S. Ewens, E.J. Moore, S.B. Gundy, and E.W. Walker by virtue of their specific positions within the House and their own varying commitment to nurturing a national literature for Canada were influential players. At the same time, in the late nineteenth century the Methodist Church expressed concern for Canada's national life, expanded its definitions about what constituted acceptable literature, and became more actively involved in secular interests through its pursuit of the social gospel. The church's concerns helped to pave the way for an extension of the House's publishing and bookselling mandate, of which its production of Canadian-authored titles was a part. Because it built upon the variety of business activities which it had established during its first fifty years, the House possessed the diversity of operations which were a necessary condition for the support of indigenous book publishing during that period. In combination with an already existing wish to develop a Canadian Methodist literature and a generally improving situtation around book publishing in Canada, these circumstances contributed toward a broader concern for Canadian letters. Making note of these factors is not to deny Briggs's 
own important role but rather to place it in context. All of these forces will come into play as one enters into an examination of surviving documentation related to the Methodist Book and Publishing House's publication of Canadian-authored titles between I879 and I9I9.

\section{RÉSUMÉ}

L'importance qui a été traditionnellement accordée à William Briggs comme principal responsable de l'engagement du Methodist Book and Publishing House envers l'écriture canadienne à la fin du dix-neuvième et au début du vingtième siècle, a laissé inexplorés et méconnus à la fois les circonstances et les individus qui ont influencé cet effort. Lorsque Briggs devint Book Steward en I 879, il assuma la direction d'une entreprise qui, au cours de ses cinquante premières années, avait établit une diversité de champs d'intérêt éditoriaux et pris conscience de sa situation canadienne. Associés à l'intérêt de l'Eglise Méthodiste envers la réalité canadienne et à sa définition de plus en plus élargie de ce que constituait une littérature acceptable à la fin du dix-neuvième siècle, ces circonstances aidèrènt à créer un environnement propice à l'engagement plus large vis-à-vis l'écriture canadienne durant l'administration de Briggs. La situation de l'édition canadienne qui allait en s'améliorant et la présence de collègues éditorialistes cléricaux, E.H. Dewart et W.H. Withrow - tous les deux des nationalistes sur le plan de la littérature - encouragèrent aussi un tel idéal. Enfin, des employés laïcs importants comme E.S. Caswell, F.S. Ewens, E.J. Moore, S.B. Gundy et E.W. Walker influencèrent les activités éditoriales de la Maison à travers leurs rôles administratifs au sein des départements de l'édition et de la vente. 


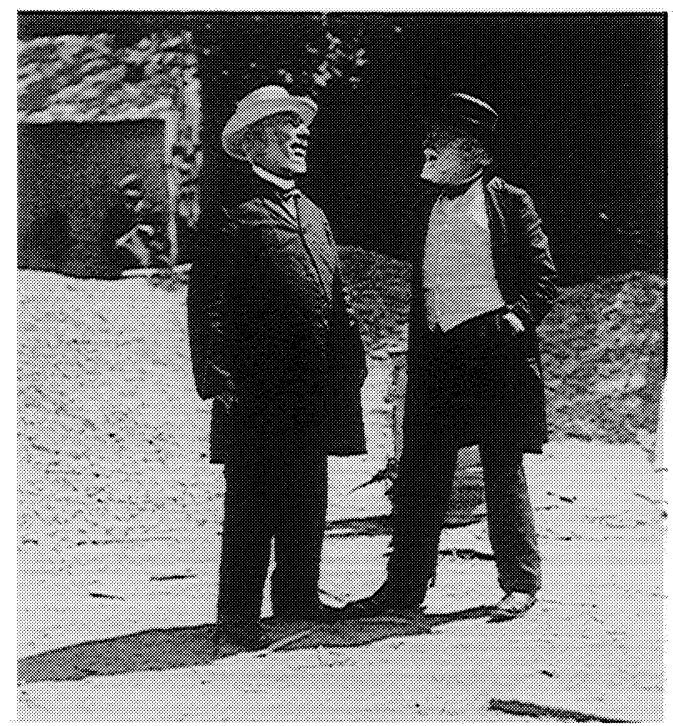

r. William Briggs and Dr. Albert Carman, c. 1913-14 (83.06r C). All photographs are reproduced with the permission of the Archives of the United Church of Canada, Victoria University Archives in the University of Toronto.

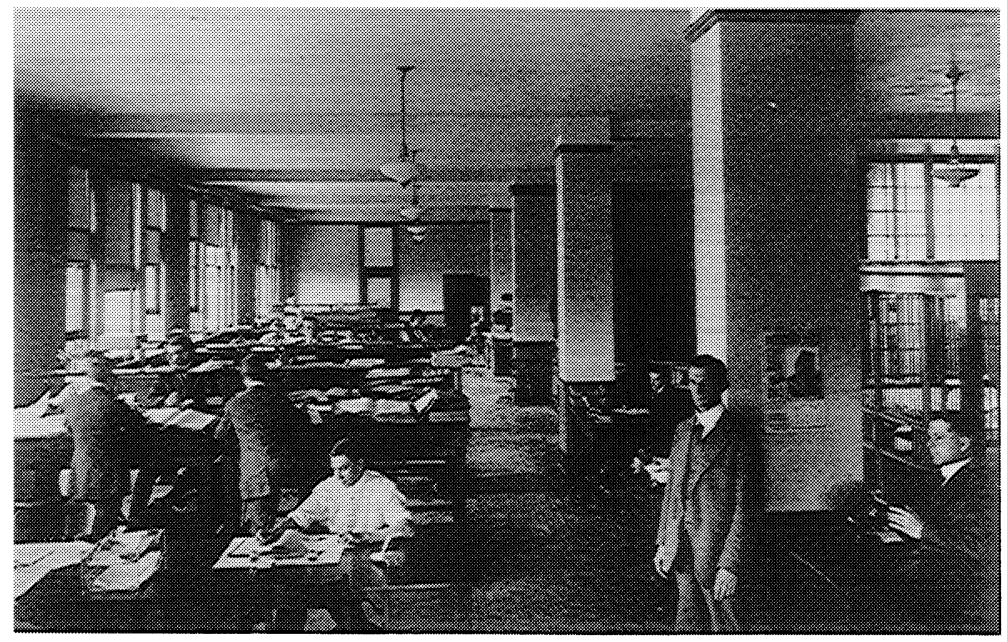

2. In the general offices, Queen and John streets, c. I9I 5. 
I54 Papers of the Bibliographical Society of Canada $33 / 2$

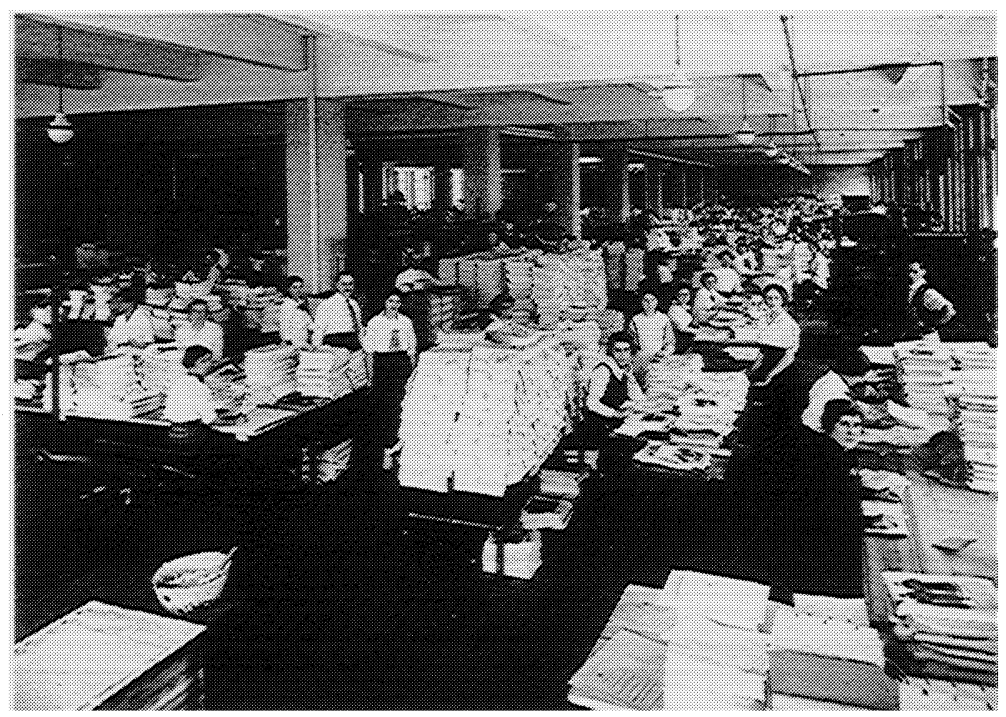

3. The bindery, Queen and John streets, c. 1915 (83.06IC).

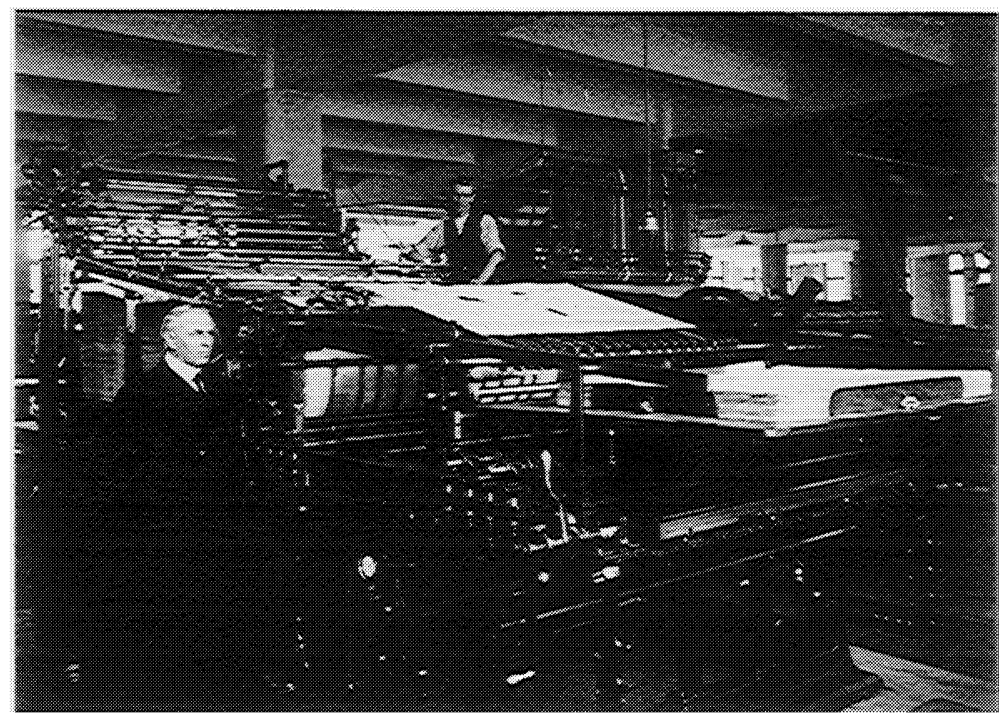

4. Printing the first Guardian in the new building, Queen and John streets, c. 1915 (83.061C). 


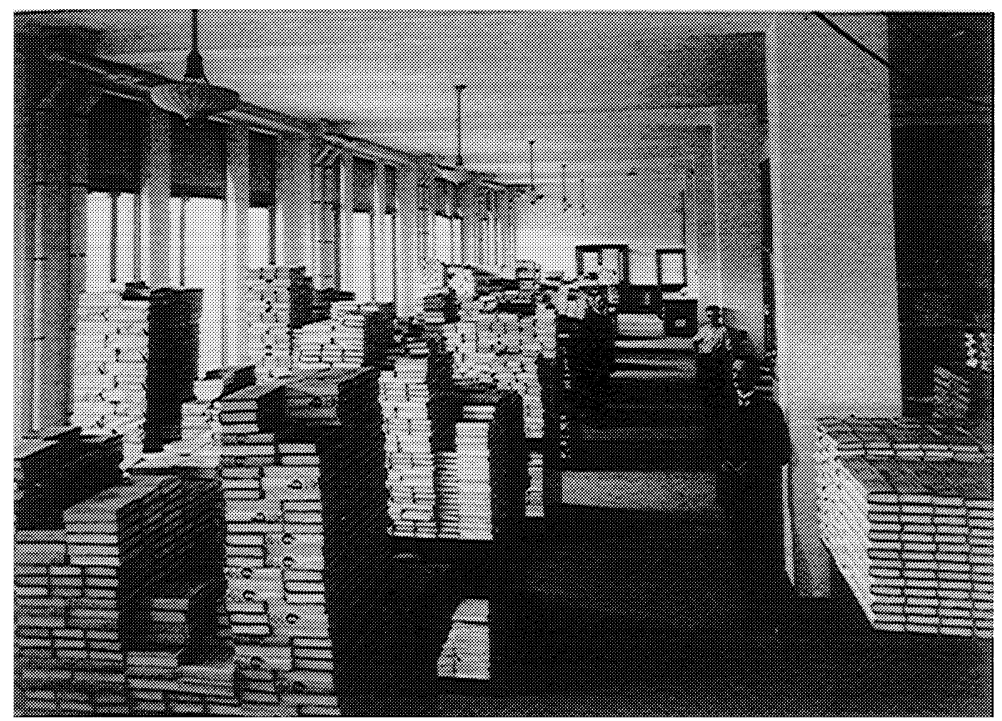

5. A section of the wholesale department, E.W. Walker in the foreground, Queen and John streets, c. I9I5 (83.06IC).

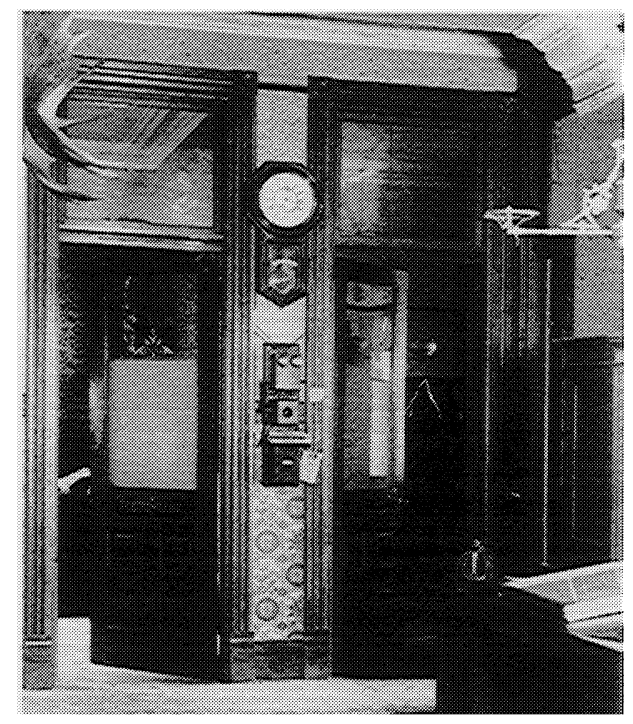

6. N Office of The Wesley buildings, Richmond St., I9I-? (9I.013 $\mathrm{PI}_{3}$ ). 


\section{NOTES}

I would like to acknowledge the assistance, encouragement and support of the following individuals: Michael Peterman, Debra Clarke, Michèle Lacombe, Sandra Campbell, Laura Zink, Edith Friskney, Jennifer J. Connor, Kay Dills, George L. Parker, Doug McCalla, Elwood Jones, John Wadland, John Wales, the inter-library loan staff at Trent University, the staffs of the various archives which appear in the notes that follow, and the Ontario Graduate Scholarship Program.

I All of these works were initiated by The Ryerson Press. The Chronicle of a Century was published for the House's hundredth anniversary in 1929 while The House of Ryerson 1829-1954 and The Ryerson Imprint were prepared in honour of its one hundred and twenty-fifth anniversary. For accuracy's sake it should be explained that 'The Ryerson Press' was adopted as the House's trade name on I July 1919; prior to that time, trade publications were issued under the imprint of the reigning Book Steward, which accounts for the many books issued under the imprint of 'William Briggs' in the late nineteenth and early twentieth centuries. The title 'The Methodist Book and Publishing House,' which had been adopted after the 1874 Methodist union, encompassed all of the House's operations - printing, bookselling, periodical and book publication - and continued to do so until early 1926 when the House's assets were formally merged with those of the Presbyterian Church in the wake of the creation of the United Church of Canada on ro June 1925.

2 Recent work relating to the Methodist Book and Publishing House and The Ryerson Press include: Christina Burr, 'The Business Development of the Methodist Book and Publishing House, 1870-1914,' Ontario History 85 (September 1993): 25 I-71; Dana Garrick, 'The United Church of Canada Board of Publication Collection: A Major Resource for the History of the Book in Canada,' Papers of the Bibliographical Society of Canada 32 (Spring 1994): I I-30; Sandra Campbell, 'Nationalism, Morality and Gender: Lorne Pierce and the Canadian Literary Canon, 1920-60,' Papers of the Bibliographical Society of Canada 32 (Fall 1994): I 35-60; Danielle Hamelin, 'The Methodist Book and Publishing House: Publishing and Canadian Nationalism' in 'Nurturing Canadian Letters: Four Studies in the Publishing and Promotion of English-Canadian Writing, I890-1920' (Ph.D. diss., University of Toronto, 1994); and Janet B. Friskney, 'Towards a Canadian "Cultural Mecca": The Methodist Book and Publishing House's Pursuit of Book Publishing and Commitment to Canadian Writing I829-1926' (Master's thesis, Trent University, 1994).

3 For a more substantial discussion of the House's early years, see Friskney, 'Chapter One The First Half Century $1829-1879$ ' in 'Towards a Canadian "Cultural Mecca."'

4 John Wesley, the founder of Methodism, established a Book Room in England in 1739. The American Methodist Book Concern was established in Philadelphia in 1789 and moved to New York in 1804 .

5 For a discussion of the relationship which existed between Methodism, politics and society in Upper Canada, see Goldwin French, Parsons \&) Politics (Toronto: 
The Ryerson Press, 1962) and John Webster Grant, A Profusion of Spires: Religion in Nineteenth-Century Ontario /Toronto: University of Toronto Press, 1988).

6 In his memoirs Anson Green recalled: '[We had felt] the need of a Press at our command, not only to explain our doctrines and polity, but more especially to fight the battles in which we were engaged for equal rights and for religious equality. We had so long been kept in the cold shades of what can scarcely be called religious toleration, that we had fully made up our minds to let our strength be known while, calmly, but firmly and persistently, we demanded equal rights with any other and all other Churches.' Green, The Life and Times of the Reverend Anson Green (Toronto: Methodist Book Room, I877), I34-5.

7 George L. Parker, The Beginnings of the Book Trade in Canada (Toronto: University of Toronto Press, 1985), ro9.

8 'Sacred Harmony,' Christian Guardian 8 (9 November 1836): 3.

9 Sunday School Guardian 6 ( July I 851): 17.

Io George Case, 'Canadian Wesleyan Literature,' Christian Guardian 36 (29 March I865): 50.

I I [W.H. Withrow], 'A Native Methodist Literature,' Canadian Methodist Magazine I (January I 875 ): 76.

I2 Ibid., 77.

I3 W.H. Withrow to William Kirby, 22 January I88I, William Kirby Papers, Archives of Ontario.

I4 John Webster Grant, The Church in the Canadian Era (Toronto: McGraw-Hill, Ryerson Ltd., 1972), 38, 42.

I5 Cited in Grant, A Profusion of Spires, 189.

I6 'Novel Reading,' Christian Guardian 23 (28 January I852): 61.

17 'Novels ar.d Novel-Reading,' Christian Guardian 50 (I9 February I879): 60.

I8 Ibid.

I9 Report of the Western Section of the Book Committee of The Methodist Church to The General Conference I886, p. 3, box 5, Board of Publication Papers, Archives of the United Church of Canada/Victoria University Archives in the University of Toronto. Unless otherwise indicated, all references to archival documents are to these records.

20 Richard Allen, 'The Background to the Social Gospel in Canada' in The Social Gospel in Canada, ed. Allen (Ottawa: National Museum of Man, I975), 20-I.

2 I Richard Allen, The Social Passion (Toronto: University of Toronto Press, I97 I), 4.

22 William H. Magney, 'The Methodist Church and the National Gospel, I884I914,' The Bulletin 28 (1968): 23.

23 'Canadian Unity,' Christian Guardian 82 (20 September I9I I): I.

24 See, for example, Mary Lu MacDonald, Literature and Society in the Canadas I817-1850 (Lewiston, New York: Edwin Mellen Press, I992) and Carl Ballstadt, ed., The Search for English-Canadian Literature (Toronto: University of Toronto Press, 1975).

25 Thomas D'Arcy McGee, 'Protection for Canadian Literature' in The Search for English-Canadian Literature, 2 I. 
26 Robert L. McDougall, 'Literary Nationalism in Canada,' Reflections from the Past, vol. I (Plattsburgh, New York: Center for the Study of Canada, I991), 23.

27 See S.M. Beckow, 'From the Watch-Towers of Patriotism: Theories of Literary Growth in English Canada, 1864-1914,' Journal of Canadian Studies 9 (August I974): 3-15.

28 Sara Jeannette Duncan, for example, offered her opinion on the problems of indiscriminate criticism and of literary nationalism in her 1888 article, 'Dangers of Literary Nationalism' in Selected Journalism, ed. Thomas E. Tausky (Ottawa: Tecumseh Press, I978), I I6-8.

29 William Wilfred Campbell, Archibald Lampman, Duncan Campbell Scott, At the Mermaid Inn, introduced by Barrie Davies (Toronto: University of Toronto Press, 1979|, 34 and 'Three Volumes of Poetry,' Books and Notions 9 (October I893): I I.

30 'Canadian Literature,' Bookseller and Stationer 2 I (February I905): 53.

3 I George L. Parker, 'A History of a Canadian Publishing House: A Study of the Relation Between Publishing and the Profession of Writing I890-1940' (Ph.D. diss., University of Toronto, I969), viii-ix.

32 For an extended discussion of Canadian writers during this period see Gordon Roper, 'New Forces: New Fiction (1880-1920),' Literary History of Canada, ed. Carl F. Klinck, 2nd ed. (Toronto: University of Toronto Press, 1976) 274-97.

33 'Gossip of the Month,' Canadian Bookman I (April I909): 5 I.

34 Parker, The Beginnings of the Book Trade in Canada, 236.

35 Parker, 'A History of a Canadian Publishing House,' 30.

36 Parker, The Beginnings of the Book Trade in Canada, 236.

37 Ibid., 256.

38 Journal of the Second General Conference of the Methodist Church of Canada I 878 (Toronto: Samuel Rose, I 878), 77-8.

39 S.P. Rose, 'William Briggs, D.D. (1836-1922)' in The Chronicle of a Century, ed. Lorne Pierce (Toronto: The Ryerson Press, 1929), 91.

40 Parker, The Beginnings of the Book Trade in Canada, 209.

4I Cited in Robson Black, 'Hours with Nation Builders: William Briggs,' Winnipeg Tribune, I I October 1913, section 2, p. I.

42 Ibid.

43 Ibid.

44 William Briggs, 'A Word from the Book Steward,' Christian Guardian 50/23 July 1879|: 236.

45 All profit and circulation figures have been obtained from the Book Committee minutes or the Book Committee Reports to the General Conference. For a detailed discussion of the House's development from an economic perspective see Burr, 'The Business Development of the Methodist Book and Publishing House, I870-1914.'

46 'Our Methodist Book Room,' Christian Guardian 5I (28 July I 880): 236.

47 Journal of Proceedings of the First United General Conference of the Methodist Church (Toronto, Halifax, Montreal: William Briggs, S.F. Huestis, C.W. Coates, I883), ror. See also George H. Cornish, Cyclopedia of Methodism in Canada 
vol. 2. (Toronto: Methodist Book and Publishing House, 1903), 358.

48 Book Committee Minutes of 6 February 1884 and 26 June 1884.

49 Journal of Proceedings of the First United Conference of the Methodist Church (Toronto: William Briggs, I 883), Ioo.

50 'Methodist Book \& Publishing House, Toronto,' Books and Notions I (July I 885): I 83 .

5 I Ibid., I 84 .

52 Parker, The Beginnings of the Book Trade in Canada, 202.

53 Ibid., 202-10.

54 Ibid., 206.

55 Agreement 83, box 7 .

56 'Our Book and Publishing Interest,' Christian Guardian 58 (7 December 1887): 774.

57 J. Barber to Samuel W. Fallis, 5 May I924, file 4, box I4.

58 Christian Guardian 60 (2 October I 889): 638 .

59 Michael Bliss, A Canadian Millionaire: The Life and Business Times of Sir Joseph Flavelle, Bart. 1858-1939 (Toronto: Macmillan of Canada, 1978), I 20.

60 Ibid.

6I William Westfall, Two Worlds: The Protestant Culture of Nineteenth-Century Ontario (Montreal \& Kingston: McGill-Queen's University Press, 1989), 195.

62 Michael Bliss, Northern Enterprise: Five Centuries of Canadian Business (Toronto: McClelland and Stewart, 1987), 346.

63 Books and Notions I (May I885): 159 and Books and Notions 6 (March I890): I 2.

64 Books and Notions 6 (April I890): I2.

65 Report of the Western Section of the Book Committee of The Methodist Church to the General Conference, 1890 , p. 4 , box 5.

66 Book Committee Minutes of 30 October 1890.

67 Magney, 'The Methodist Church and the National Gospel, I884-19I4,' 21.

68 Ibid., 37.

69 Book Committee Minutes of 23 November 1892.

70 Withrow to Kirby, 18 June 1904, Kirby Papers.

71 In his work, The Sense of Power: Studies in the Ideas of Canadian Imperialism I867-1914 (Toronto: University of Toronto Press, 1970), Carl Berger has described Canadian imperialism as 'one variety of Canadian nationalism,' p. 9. He later goes on to explain: 'Canadian imperialism rested upon an intense awareness of Canadian nationality combined with an equally decided desire to unify and transform the British Empire so that this nationality could attain a position of equality within it,' p. 49. The attitude adopted by the Methodist Church in the late nineteenth and early twentieth centuries very much reflected this position. For further discussion of imperialism and nationalism, see also Carl Berger, ed., Imperialism and Nationalism, 1884-1914: A Conflict in Canadian Thought (Toronto: Copp, Clark Publishing Co., I969).

72 Burr, 'The Business Development of the Methodist Book and Publishing House, I870-I9I4,' 26I. 
73 Book Committee Minutes of 18 May 1892.

74 Book Committee Minutes of 15 November 1893.

75 H. Pearson Gundy, 'The Development of Trade Book Publishing in Canada' in Royal Commission on Book Publishing: Background Papers. (Ontario: Queen's Printer and Publisher, 1972), r 8.

76 Parker, The Beginnings of the Book Trade in Canada, 236.

77 For a discussion of the series, see Michael Bliss, "Pure Books on Avoided Subjects": Pre-Freudian Sexual Ideas in Canada,' Historical Papers 1970, 89-108.

78 Parker, 'A History of a Canadian Publishing House,' 4I.

79 Ibid.

80 William Briggs Agreements, boxes 6-9.

8I Mary Vipond, 'Best Sellers in English Canada, I899-19 I 8: An Overview,' Journal of Canadian Fiction 24 (1979): 103.

82. Cited in Roper, 'New Forces: New Fiction, I880-1920,' 284.

83 Vipond, 'Best Sellers in English Canada, I899-1918: An Overview,' I I 3-9.

84 Report of the Western Section of the Book Committee to the General Conference I902, box 5 .

85 Book Committee Minutes of ro May 1900.

86 The most interesting of these actually used reverse psychology. Entitled 'Don't Subscribe for The Christian Guardian,' it offered seven reasons not to subscribe. Among them were '[i]f you wish the Methodist Church were dead; for it is The Guardian's special business to help to keep the church alive,' '[i]f you have money and want to keep it; for the church of our fathers needs money for missions, for education and for a hundred other things, and The Guardian believes that giving is a means of grace,' and '[i]f you want to build up any other nation at the expense of Canada; for The Guardian is Canadian and British from cover to cover, and expects to remain so.' See Christian Guardian 78 /2 January 1907): 4 .

87 General Catalogue of Books, Published and On Sale at The Methodist Book and Publishing House (Toronto: Printed at the Guardian Book and Job Establishment, I876-7), back cover, box 5 .

88 'The Book Room's Announcements,' Christian Guardian 76 (Io May I905): 2.

89 Report of the Western Section of the Book Committee to the General Conference I906, box 5 .

90 Agreement \# I 73, box 5, D.J. Goggin materials re: claims of Warwick Bros. \& Rutter, Merrill Denison Papers, Queen's University Archives.

9I Book Committee Minutes of 4 December I9I3.

92 'News of the Trade,' Bookseller and Stationer 34 (August 1918): 22.

93 'Two-Million Dollar Printing and Publishing Plant,' Printer and Publisher 25 (February 1916): 19.

94 Barber to Fallis, 5 May 1924 and Edward J. Moore, 'The New Home of Our Publishing House,' Christian Guardian 86 (I8 August I915): 20.

95 Book Committee Minutes of 14 November 1900.

96 Book Committee Minutes of I 6 May I 901 .

97 'Books Classed Unfit for Public,' Toronto World, Io April I9 I2, p. I. 
98 'A Fuss Over Two Books,' Toronto Evening Telegram, Io April I9 12, p. 25.

99 William Briggs Agreements, Agreement \#252, box 9.

I00 Book Committee Minutes of 9 May 19 I 2.

Ior See 'The Book Room Site,' Christian Guardian 84 (10 December I913): 16-8. The inquiry revealed that Briggs had originally chosen another property. While he was negotiating for it, several individuals connected with the House had purchased the Queen and John Street property. When negotiations on the first property fell through, Briggs reassessed the available real estate in the city and decided to open negotiations on Queen and John Streets. It was only after the purchase had gone through, he claimed, that he had found out who the actual owners were; he had not known previously because negotiations had taken place through a third party.

I02 Ben. H. Spence, 'The Book Room Site,' (letter to the editor) Christian Guardian $84(22$ October I 9 I 3$): 27$.

I03 Ernest Thomas, 'Why Have a Church Book Room?' (letter to the editor) Christian Guardian 84 (24 December I913): 2.

I04 Ibid.

I05 C.E. Bland, 'Our Book Room Policy,' (letter to the editor) Christian Guardian 85 (7 January I9I4): 22.

I06 Bliss, A Canadian Millionaire, I2. On occasion the Book Committee would make an explicit link between the House's prosperity and God's benevolence. For example, the Book Committee Minutes of I2 May I9I5: 'That having examined the annual statement and balance sheet of the Book and Publishing House for the last year showing as it does a most handsome profit upon the year's operations ... resolved that we express our gratitude to Almight[y] God for His kind providence and rich blessing upon our enterprise granting us such splendid success ...'

107 Gundy, 'The Development of Trade Book Publishing in Canada,' 24.

I08 See book advertisements in the Christian Guardian for the years I9I4 to 1918.

I09 'Worth While War Books,' Christian Guardian 88 (Io January I917): 23.

I ro 'Happenings of the Month,' Printer and Publisher 24 (January I9 I 5 ): 44.

I I B Book Committee Minutes of I I May I9I 5.

Ir 2 William Briggs, 'A Word from the Book Steward,' Christian Guardian 88 (28 February I9I 7 l: 12 .

II3 'News of the Trade,' Bookseller and Stationer 34 (August I9 18): 22.

II4 Gordon H. Allison, The Westminster Company (Master's thesis, University of Toronto, 1962), 67.

II5 'News of the Trade,' Bookseller and Stationer 34 (August 1918): 22.

II6 Ibid.

II7 Journal of Proceedings of the Tenth General Conference of The Methodist Church Oct. 2-17, 1918 (Toronto: William Briggs, 1918), I 17.

I 8 Pierce, The House of Ryerson, 26.

I 9 E.H. Dewart, ed., Selections from Canadian Poets, Literature of Canada [Reprint] Series (Toronto: University of Toronto, I973), vii. I 20 Ibid., $x$, xiv, xix. 
I2 I See 'Canadian Poetry,' Christian Guardian 52 (26 January I88I): 28; 'Canadian Literature,' Christian Guardian 55 (24 September 1884): 3 I 8; and 'Have We a Canadian Literature?' Christian Guardian 59 (22 February I888): 120.

122 Dewart, Selections from Canadian Poets, ix.

I23 Margery Fee, 'English-Canadian Literary Criticism, I890-1950: Defining and Establishing a National Literature' (Ph.D. diss., University of Toronto, 198 I), I.

I24 Withrow to A. Morse, Reeve of Grimsby, 28 April I87I, W.H. Withrow Papers, Archives of Ontario.

I25 Letters from D.D. Whedon of the American Methodist Book Concern to Withrow reveal the establishment's support of Canadian writers. Whedon wrote on 27 September I $87 \mathrm{I}$ : 'We have not from the beginning regarded nationalities in our literature. ... Our wish is to promote Methodist authorship on both sides of the ocean and on both sides of the lakes.' Then on 9 October $187 \mathrm{I}:{ }^{\prime}$ '. . y y ou] loyal brethren ... ought to be reminded that we take English literature as readily as we do our own. Besides, what favor do Canada [sic] authors expect in England? What encouragement from English publishers, or liberality of nature from British periodicals? We stand ready to deal with Canadian literature as liberally as if it were South of the lakes.' files 4 and 28, Withrow Papers.

I 26 'Rev. William H. Withrow, M.A., D.D., F.R.S.C.' in Commemorative Biographical Record of the County of York, Ontario (Toronto: J.H. Beers \& Co., I907), 30.

127 S.S. Nelles to Withrow, 27 March r871, Withrow Papers.

128 'Methodist Book \& Publishing House, Toronto,' I 84.

I29 Withrow to Kirby, n.d. [c. I880] and Withrow to Kirby, 5 March 1887, Kirby Papers.

I 30 Letters from Withrow to Kirby, Kirby Papers and Withrow, Neville Trueman, The Pioneer Preacher (Toronto: William Briggs, I900), I I.

I 3 I Withrow, 'Recent Canadian Poetry,' Canadian Methodist Magazine 27 (March I 888): 245 .

I 32 Ibid., 25 I.

I 33 John Webster Grant, 'Ryerson Press, The,' Oxford Companion to Canadian Literature, ed. William Toye (Toronto: Oxford University Press, 1983), 722.

I 34 Pierce, The House of Ryerson, 19.

I 35 I have encountered conflicting dates regarding when Caswell started in this position. E.J. Moore's article, 'Canada's First Publishing House: A History and An Appreciation,' Canadian Bookman I (January I919): 72, states that Caswell took on this role in the I88os. However, the Who's Who for 1937 gives the year I 892. I lean toward the latter date. It should also be noted that while in this position Caswell was, at different times, variously described as a clerk, the reader, the literary editor, and the publishing department manager as well as the book publishing department manager. For simplicity's sake and because it best reflects the nature and variety of the position, I am going to use the latter term.

I 36 Grant, 'Ryerson Press, The,' 722.

I 37 Caswell to Traill, I7 November I897, Traill Family Papers, MG 29 D8I, National Archives of Canada. 
${ }_{13} 8$ 'What Men and Firms in the Trade are Doing this Month,' Bookseller and Stationer 24 (August 1908), 38 and cited in 'Caswell, Edward S.,' Canadian Men and Women of the Times, ed. Henry J. Morgan (Toronto: William Briggs, I9I2), 213.

139 Saturday Night 23 (23 October 1909): 7.

140 'Toronto's New Assistant-Librarian,' Canadian Bookman I (October 1909): I69.

I4I 'Mr. Caswell's Promotion,' Christian Guardian 80 (1 3 October I909): 3.

142 See Burr, 'The Business Development of the Methodist Book and Publishing House, I870-1914,' 264.

143 Ibid.

144 'Locke, George Herbert' in Macmillan Dictionary of Canadian Biography (Toronto: Macmillan, 1978), 468.

145 E.S. Caswell, 'Canadian Books for Canadian Readers,' Bookseller and Stationer 23 (August 1907): 26-7.

I46 E.S. Caswell, 'Time on Our Side,' Canadian Magazine 40 (April I913): 58I-2.

I47 Caswell, 'Canadian Literature,' Christian Guardian 80 (24 November 1909): 8.

I48 Ibid.

I49 Ibid.

I 50 Bookseller and Stationer 24 (October 1908): 54.

I 5 I Caswell, 'The Late F.S. Ewens: A Tribute,' Christian Guardian 85 (I4 January 1914): 2.

152 'Late Sidney Ewens Was Greatly Loved,' Toronto Globe, 7 January 1914, p.7.

153 Caswell, 'The Late F.S. Ewens' and 'F.S. Ewens Dies Suddenly,' Bookseller and Stationer 30 (February 1914): 31 .

I54 Deacon to Emily Murphy, I4 January 1923, William Arthur Deacon Papers, Thomas Fisher Rare Book Library, University of Toronto.

I55 'A Canadian Branch,' Bookseller and Stationer 20 (April I904): 125.

I 56 Gundy's resignation, 8 January I904, file 24 , box Io.

I 57 Ibid.

158 See the City of Toronto Assessment Records for I904-1910.

I 59 Paul Duval, 'You Should Know - Ernest Walker,' Bookseller and Stationer 6I (November 1945): 15.

I60 'Briggs' Travellers,' Bookseller and Stationer 35 (March 1919): 5 I.

I6I Sandra Campbell to Janet Friskney, 24 October 1993. Professor Campbell's letter provides information about E.W. Walker obtained from her interview with C.H. Dickinson, Book Steward of The Ryerson Press from 1937 to 1964. 
